\title{
DAMPAK SURFAKTAN BERBAHAN AKTIF Na-ABS TERHADAP DAYA TETAS TELUR IKAN KARPER (Cyprinus carpio) DALAM SKALA LABORATORIUM
}

\author{
Maulina Septia Prahastuti, Churun Ain, Bambang Sulardionol \\ Program Studi Manajemen Sumberdaya Perairan, Jurusan Perikanan \\ Fakultas Perikanan dan Ilmu Kelautan, Universitas Diponegoro
}

\begin{abstract}
ABSTRAK
Penurunan kualitas lingkungan disebabkan adanya bahan pencemar, contohnya limbah deterjen yang mengandung surfaktan berbahan aktif Na-ABS. Deterjen dapat memberikan dampak negatif terhadap proses kehidupan organisme di dalamnya, salah satunya proses penetasan telur ikan. Fase telur merupakan stadia yang rentan dan jauh lebih sensitif terkena pengaruh dari luar atau dari lingkungan. Berdasarkan hal tersebut, diperlukan adanya masukan mengenai dampak surfaktan terhadap daya tetas telur ikan karper (C. carpio). Tujuan penelitian ini adalah menentukan nilai $\mathrm{LC}_{50}-96$ jam dari deterjen berbahan aktif surfaktan jenis NA-ABS, dan mengetahui pengaruh kandungan surfaktan terhadap daya tetas telur ikan karper (C. carpio). Materi yang digunakan dalam penelitian ini adalah ikan karper (C. carpio) dan telurnya. Metode yang digunakan dalam penelitian ini adalah eksperimental laboratoris. Rancangan percobaan yang digunakan adalah Rancangan Acak Lengkap (RAL) dengan 5 perlakuan yang terdiri dari 3 ulangan. Tahap penelitian terdiri dari: uji pendahuluan, uji lanjut, Persiapan materi telur ikan, uji utama, perhitungan daya tetas telur, dan pengukuran variabel kualitas air. Perlakuan yang diberikan pada uji utama adalah pemberian deterjen terhadap telur ikan dengan konsentrasi $6,25 \%, 12,5 \%, 25 \%, 50 \%$, dan $100 \%$ dari nilai $\mathrm{LC}_{50^{-}} 96$ jam, yaitu $1,35 \mathrm{mg} / \mathrm{L}, 2,70 \mathrm{mg} / \mathrm{L}, 5,40 \mathrm{mg} / \mathrm{L}, 10,80$ $\mathrm{mg} / \mathrm{L}$, dan 21,60 mg/L. Hasil penelitian menunjukkan bahwa nilai $\mathrm{LC}_{50}-96$ jam surfaktan terhadap ikan karper (C. carpio) adalah $21,60 \mathrm{mg} / \mathrm{L}$. Kualitas air selama penelitian, yaitu: suhu $24,37-28,30^{\circ} \mathrm{C}$, oksigen terlarut 2,37 - 4,00 mg/L, dan $\mathrm{pH} 7$. Hasil analisis data menggunakan ANOVA faktorial menunjukkan bahwa konsentrasi deterjen berpengaruh nyata terhadap daya tetas telur ikan karper $(\mathrm{p}<0,05)$, semakin besar konsentrasi deterjen maka persentase daya tetas telur setiap harinya semakin kecil. Pengaruh deterjen mulai terlihat jelas pada konsentrasi 5,40 mg/L dengan waktu kritis yaitu pada hari kedua.
\end{abstract}

Kata kunci: Surfaktan, Daya Tetas Telur, Ikan Karper (C. carpio)

\begin{abstract}
Pollutans, such as surfactant detergent with Na-ABS active compounds caused enviromental degradation. Detergent has a negative impact for the living process of aquatic organisms, for example at the fish hatchery phase. Eggs are vulnerable and more sensitive from outside influences and from the environment. Based on this, it is necessary to know about the impcat of surfactant on hatching rate of fish, such as carp $(C$. carpio). The purpose of this study was determined $L C_{50^{-}}-96$ hours value of detergent with Na-ABS active compounds to Carp (C. carpio), and determined the impact of surfactant to hatching rate of carp's egg. The material used in this study was carp (C. carpio) and it's eggs. This study used experimental laboratory method. Experiment design used randomized design with 5 treatments and each consisted of 3 replications. Phase of this study consisted of: preliminary test, definitive test, Preparation of material carp's egg, main test, calculated hatching rate of carp, and measured the variables of water quality. Treatment in the main test was gave detergents to fish eggs with the concentrations: $6.25 \%, 12.5 \%, 25 \%, 50 \%$, and $100 \%$ of it's $L_{50} C^{-96}$ hours value, which is $1.35 \mathrm{mg} / \mathrm{L}, 2.70 \mathrm{mg} / \mathrm{L}, 5.40 \mathrm{mg} / \mathrm{L}, 10.80 \mathrm{mg} / \mathrm{L}$, and $21.60 \mathrm{mg} / \mathrm{L}$. The results showed that the $L C_{50^{-}} 96$ hours value of surfactant to carp was $21.60 \mathrm{mg} / \mathrm{L}$. Water quality during the study: temperature from 24.37 to $28.30^{\circ} \mathrm{C}$., dissolved oxygen from 2.37 to $4.00 \mathrm{mg} / \mathrm{L}$, and $\mathrm{pH}$ 7. The result of data analysis with ANOVA showed that detergent concentration influenced the hatching rate of carp $(p<0.05)$, with increase of detergent concentration, the hatching rate of carp decrease day by day. Influence of detergent has been seen clearly at concentration $5.40 \mathrm{mg} / \mathrm{L}$ with critical time at the second day.
\end{abstract}

Keywords: Surfactant, Hatching Rate, Carp (C. carpio)

1) Penulis Penanggung Jawab 


\section{Pendahuluan}

Masalah kualitas lingkungan merupakan persoalan yang serius bagi banyak negara, termasuk Indonesia. Salah satu penyebab penurunan kualitas lingkungan adalah pencemaran air yang didukung oleh adanya pertumbuhan ekonomi dan laju peningkatan populasi penduduk yang sedemikian cepat (Effendi, 2000). Sumber pencemar baik yang ada di darat maupun di perairan berasal dari berbagai aktivitas manusia seperti aktivitas rumah tangga, industri, dan pertanian. Limbah dari aktivitas rumah tangga yang berdampak buruk bagi lingkungan adalah deterjen. Deterjen tersusun atas bahan baku penyusun utama yaitu surfaktan yang berbahan aktif Na-ABS (Natrium Alkyl Benzene Sulphonate) yang merupakan deterjen keras. Deterjen tersebut sukar dirusak oleh mikroorganisme (non biodegradable) sehingga dapat menimbulkan pencemaran lingkungan (Rubiyatadji, 1993).

Deterjen dengan kepekatan tinggi akan menghambat masuknya oksigen dari udara ke dalam larutan uji (air limbah deterjen) sehingga lama kelamaan ikan akan kehabisan oksigen sampai akhirnya mati. Adanya deterjen di perairan juga dapat mempercepat pertumbuhan tumbuhan air, misalnya ganggang dan eceng gondok yang menyebabkan perairan menjadi dangkal dan biota air banyak yang mati karena kekurangan oksigen.

Beberapa penelitian telah dilakukan terkait dengan toksisitas suatu bahan pencemar terhadap ikan karper, tetapi dari penelitian tersebut belum ada yang meneliti tentang nilai toksisitas (LC) suatu bahan pencemar terhadap daya tetas telur ikan karper ( $C$. carpio), dimana fase telur dalam daur hidup ikan merupakan stadia yang rentan dan jauh lebih sensitif terkena pengaruh dari luar atau dari lingkungan, jika terus terpapar oleh bahan pencemar seperti deterjen, maka dapat merusak sumberdaya ikan tersebut. Efektivitas dampak dari surfaktan terhadap daya tetas telur tergantung pada konsentrasi kandungan surfaktan di dalam perairan. Oleh karena itu untuk mengetahui bagaimana efektivitas dampak tersebut, perlu dilakukan penelitian terkait dampak surfaktan berbahan aktif Na-ABS terhadap daya tetas telur ikan karper (C. carpio) dalam skala laboratorium

Tujuan dari penelitian ini adalah untuk menentukan konsentrasi sublethal dari surfaktan jenis Na-ABS terhadap ikan karper $\left(C\right.$. carpio) dilihat dari nilai $\mathrm{LC}_{50}-96$ jam dan mengetahui pengaruh kandungan surfaktan terhadap daya tetas telur ikan karper (C. carpio) yang diuji secara laboratoris. Penelitian dilakukan dengan 2 tahap. Tahap pertama, yaitu uji pendahuluan dan uji lanjut, dilaksanakan pada bulan November 2012. Tahap kedua, yaitu uji utama dilaksanakan pada bulan Desember 2012 di Balai Benih Ikan Ungaran, Kabupaten Semarang.

\section{Metode Penelitian}

Materi yang digunakan dalam penelitian ini adalah benih ikan Karper (C. carpio) dengan ukuran panjang $3-5 \mathrm{~cm}$ dan berat $3-6$ gram yang digunakan dalam uji pendahuluan dan uji lanjut untuk mengetahui nilai $\mathrm{LC}_{50}$ dari surfaktan terhadap ikan tersebut, dan telur ikan karper (C. carpio) yang digunakan dalam uji utama yang akan diamati daya tetasnya di dalam larutan surfaktan yang konsentrasinya berbeda sesuai dengan nilai $\mathrm{LC}_{50}$-nya.

Alat yang digunakan dalam penelitian ini adalah akuarium sebanyak 18 buah ukuran 30 x 20 x $19 \mathrm{~cm}$ yang diisi air dengan volume $10 \mathrm{~L}$, aerator, timbangan elektrik dengan ketelitian 0,01 gram, kaca pembesar, DO Meter dengan ketelitian $0,01 \mathrm{mg} / \mathrm{L}$, pH paper universal, gelas ukur ukuran $10 \mathrm{ml}$ dan $100 \mathrm{ml}$, alat tulis, dan kamera digital. Bahan yang digunakan dalam penelitian adalah deterjen yang mengandung $22 \%$ surfaktan jenis Na-ABS (Natrium Alkyl Benzene Sulphonate) yang diujikan pada telur ikan dengan konsentrasi berbeda sesuai dengan nilai $\mathrm{LC}_{50}$ yang didapatkan dari uji pendahuluan.

Metode yang digunakan dalam penelitian ini adalah eksperimental laboratoris, dan rancangan yang digunakan adalah Rancangan Acak Lengkap (RAL). Penelitian dilakukan dalam beberapa tahap, yaitu:

1. Uji pendahuluan

Uji pendahuluan dilakukan untuk mendapatkan konsentrasi ambang atas $\left(\mathrm{LC}_{100}-24 \mathrm{jam}\right)$ yaitu konsentrasi terendah dimana semua ikan uji mati dalam waktu pendedahan 24 jam, dan ambang bawah (LC $0^{-} 48$ jam), yaitu konsentrasi tertinggi dimana semua ikan uji masih hidup dalam waktu pendedahan 48 jam (APHA, 1995). Uji ini dilakukan dengan menggunakan 5 perlakuan berdasarkan basis 10 deret logaritmik, yaitu $0,01 \mathrm{mg} / \mathrm{L} ; 0,1$ $\mathrm{mg} / \mathrm{L} ; 1 \mathrm{mg} / \mathrm{L} ; 10 \mathrm{mg} / \mathrm{L}$; dan $100 \mathrm{mg} / \mathrm{L}$. Setiap akuarium diisi air sebanyak $10 \mathrm{~L}$, dipasang aerator, dan ikan uji dimasukkan sebanyak 10 ekor untuk tiap akuarium.

2. Uji lanjut

Uji lanjut dilakukan untuk mengetahui konsentrasi dimana ikan uji mati 50\% selama jangka waktu dedah 96 jam ( $\mathrm{LC}_{50^{-}}-96$ jam). Untuk menentukan konsentrasi uji lanjut berdasarkan hasil dari uji pendahuluan adalah sebagai berikut:

$$
\begin{aligned}
& \log \left(\frac{N}{n}\right)=k \log \left(\frac{a}{n}\right) \\
& \frac{a}{n}=\frac{b}{a}=\frac{c}{b}=\frac{d}{c}=\frac{e}{d}
\end{aligned}
$$

Keterangan:

$\begin{array}{ll}\mathrm{N} & = \\ \mathrm{n} & = \\ \mathrm{a} & = \\ \mathrm{k} & =\end{array}$

Konsentrasi ambang atas

Konsentrasi ambang bawah

Konsentrasi terkecil dalam deret konsentrasi yang ditentukan

Jumlah konsentrasi yang diujikan 
Perhitungan persamaan logaritma di atas menghasilkan konsentrasi surfaktan deterjen yang digunakan untuk uji lanjut. Perlakuan dalam uji lanjut dilakukan dengan diferensiasi 5 konsentrasi surfaktan yang berbeda dan 3 kali pengulangan.

3. Uji utama

Uji utama dilakukan untuk mengetahui pengaruh dari surfaktan terhadap daya tetas telur ikan dalam waktu pengamatan 7 hari. Berdasarkan standar USEPA (2002), konsentrasi yang digunakan dalam uji utama adalah $6,25 \%, 12,5 \%, 25 \%, 50 \%$, dan $100 \%$ dari nilai $\mathrm{LC}_{50}-96$ jam.

4. Perhitungan daya tetas telur ikan

Untuk melakukan perhitungan daya tetas telur ikan, kita perlu menghitung jumlah telur ikan yang menetas. Perhitungan telur ikan dalam penelitian ini dilakukan dengan metode hitung jumlah, yaitu menghitung telur hidup satu demi satu secara sensus. Menurut Billard et al., (1995), telur yang hidup berwarna kuning kecoklatan dan menempel pada kakaban, sedangkan telur yang mati akan kehilangan transparansinya menjadi keputihputihan atau pucat dan hidupnya melayang di perairan.

5. Kualitas air

Parameter kualitas air yang diukur yaitu: suhu, oksigen terlarut (DO) yang diukur menggunakan DO Meter, dan $\mathrm{pH}$ yang diukur menggunakan $\mathrm{pH}$ paper universal. Pengukuran kualitas air dilakukan setiap hari untuk setiap akuarium selama 7 hari. Menurut Bangsa (2013), ketiga parameter tersebut dianggap sebagai faktor yang memberikan efek langsung (direct factor) terhadap penetasan telur ikan.

Data mortalitas ikan pada uji lanjut diuji normalitasnya dengan bantuan program TOXSTAT, sedangkan untuk mendapatkan nilai $\mathrm{LC}_{50}-96 \mathrm{jam}$ digunakan perhitungan analisa probit menurut Koesoemadinata (1983), sebagai berikut:

$$
\mathrm{b}=\frac{\sum \mathrm{XY}-1 / \mathrm{n} \sum \mathrm{X} \sum \mathrm{Y}}{\sum \mathrm{X}^{2}-1 / \mathrm{n}\left(\sum \mathrm{X}\right)^{2}}
$$

Persamaan regresi: $\mathrm{Y}=\mathrm{a}+\mathrm{bX}$

$\mathrm{LC}_{50}-96$ jam $=$ antilog $\mathrm{m}$

Dimana,

$$
\mathrm{m}=\frac{5-\mathrm{a}}{\mathrm{b}}
$$

Keterangan:

$\begin{array}{ll}\mathrm{Y} & =\text { Probit mortalitas ikan uji } \\ \mathrm{X} & =\text { logaritma konsentrasi } \\ \mathrm{a} & =\text { Konstanta } \\ \mathrm{b} & =\text { Slope } \\ \mathrm{m} & =\text { Nilai X pada Y } 50 \%\end{array}$

Daya tetas telur ikan (Hatcing Rate) diketahui dengan memasukkan data jumlah telur yang menetas ke dalam rumus perhitungan daya tetas telur menurut Effendie (1979), sebagai berikut:

$$
\operatorname{HR}(\%)=\frac{a \times 100 \%}{a+b}
$$

Data daya tetas telur yang telah didapatkan kemudian diuji dengan uji normalitas untuk mengetahui apakah data tersebut terdistribusi normal atau tidak dan uji homogenitas untuk mengetahui apakah data tersebut homogen (berasal dari varians yang sama) atau tidak. Setelah melewati kedua uji tersebut kemudian dilakukan uji Anova dua arah (two factorial design) untuk mengetahui apakah ada pengaruh konsentrasi deterjen berbahan aktif surfaktan jenis Na-ABS terhadap daya tetas telur ikan (hatching rate). Pengolahan data statistik daya tetas telur ikan ini menggunakan program SPSS Versi 16. Kaidah pengambilan keputusan menggunakan nilai

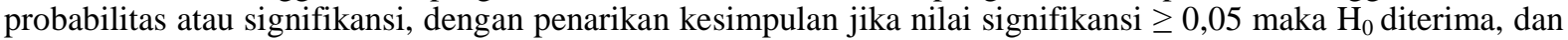
jika nilai signifikansi $<0,05$ maka $\mathrm{H}_{0}$ ditolak. Apabila hasil analisis menunjukkan perbedaan dalam taraf kepercayaan 95\% maka dilanjutkan dengan uji Duncan untuk menguji variabel/kelompok mana yang tidak berbeda atau tidak memiliki perbedaan yang signifikan dengan kelompok lainnya.

\section{Hasil dan Pembahasan}

1. Uji pendahuluan

Uji pendahuluan bertujuan untuk menetapkan konsentrasi ambang atas dan ambang bawah yang dilakukan dengan cara mengamati mortalitas ikan karper (C. carpio) dalam waktu 48 jam. Uji ini dilakukan menggunakan 5 perlakuan/konsentrasi dengan 5 akuarium yang masing-masing diisi 10 ekor ikan. Mortalitas ikan karper (C. carpio) pada uji pendahuluan dapat dilihat pada Tabel 1. 
Tabel 1. Mortalitas Ikan Karper (C. carpio) pada Uji Pendahuluan

\begin{tabular}{|c|c|c|c|c|}
\hline \multirow{2}{*}{ No. } & \multirow{2}{*}{$\begin{array}{c}\text { Konsentrasi Deterjen } \\
(\mathrm{mg} / \mathrm{L})\end{array}$} & \multicolumn{2}{|c|}{ Mortalitas } & \multirow{2}{*}{ Jumlah } \\
\hline & & 24 Jam & 48 Jam & \\
\hline 1. & 0,01 & - & - & - \\
\hline 2. & 0,1 & - & - & - \\
\hline 3. & 1 & - & - & - \\
\hline 4. & 10 & - & - & - \\
\hline 5. & 100 & 10 & - & 10 \\
\hline
\end{tabular}

Keterangan: $(-)=$ Tidak dilakukan pengamatan

Berdasarkan tabel 1 di atas, dapat dilihat bahwa deterjen berbahan aktif surfaktan jenis Na-ABS memiliki nilai ambang atas $100 \mathrm{mg} / \mathrm{L}$. Konsentrasi tersebut merupakan konsentrasi terendah dimana seluruh ikan uji (100\%) mati dalam waktu 24 jam. Nilai ambang bawah adalah $10 \mathrm{mg} / \mathrm{L}$. Konsentrasi tersebut merupakan konsentrasi tertinggi dimana ikan uji masih hidup seluruhnya (100\%) dalam waktu 48 jam. Menurut Husni (2010), uji pendahuluan dilakukan untuk menentukan batas kisaran kritis (critical range test) yang menjadi dasar dari penentuan konsentrasi yang digunakan dalam uji lanjutan atau uji toksisitas sesungguhnya, yaitu konsentrasi yang dapat menyebabkan kematian terbesar mendekati 50\% dan kematian terkecil mendekati $50 \%$.

2. Uji lanjut

Uji lanjut dilakukan menggunakan 5 konsentrasi yang didapat dengan cara menguraikan secara logaritma nilai ambang atas dan ambang bawah yang diperoleh dari uji pendahuluan dan memasukkannya ke dalam rumus (1). Setelah dilakukan perhitungan, maka didapatkan konsentrasi yang digunakan pada uji lanjut adalah: $\mathrm{A}=15,85 \mathrm{mg} / \mathrm{L}, \mathrm{B}=25,12 \mathrm{mg} / \mathrm{L}, \mathrm{C}=39,81 \mathrm{mg} / \mathrm{L}, \mathrm{D}=63,09 \mathrm{mg} / \mathrm{L}$, dan $\mathrm{E}=99,98 \mathrm{mg} / \mathrm{L}$. Hasil uji lanjut ini menunjukkan jumlah mortalitas ikan dalam waktu 96 jam. Mortalitas ikan karper (C. carpio) pada uji lanjut dapat dilihat pada Tabel 2.

Tabel 2. Mortalitas Ikan Karper (C. carpio) pada Uji Lanjut

\begin{tabular}{ccccccc}
\hline \multirow{2}{*}{ No. } & $\begin{array}{c}\text { Konsentrasi } \\
\text { Deterjen (mg/L) }\end{array}$ & \multirow{2}{*}{ Jumlah Ikan Uji } & \multicolumn{3}{c}{ Ulangan } & \multirow{2}{*}{ Jumlah } \\
\cline { 4 - 5 } & & 30 & 2 & II & III & \\
\hline 1. & 15,85 & 30 & 6 & 6 & 1 & 3 \\
2. & 25,12 & 30 & 8 & 6 & 9 & 16 \\
3. & 39,81 & 30 & 8 & 9 & 10 & 23 \\
4. & 63,09 & 30 & 10 & 10 & 10 & 30 \\
5. & 99,98 & & & & & \\
\hline
\end{tabular}

Hasil uji normalitas pada mortalitas ikan karper (C. carpio) menggunakan program TOXSTAT, didapatkan nilai chi-square hitung sebesar 4, 2237 dan nilai chi-square tabel sebesar 13, 277; sehingga dapat disimpulkan bahwa data mortalitas ikan karper (C. carpio) tersebar normal. Hasil uji lanjut selama 96 jam menunjukkan bahwa ikan uji paling banyak mati pada konsentrasi tertinggi, yaitu 99,98 mg/L dengan kematian 10 ekor pada setiap ulangan. Sebaliknya, ikan uji ditemukan paling banyak bertahan hidup pada konsentrasi terendah, yaitu 15,85 mg/L dengan kematian $0-2$ ekor di setiap ulangan (Tabel 2). Berdasarkan hasil tersebut dapat disimpulkan bahwa semakin tinggi konsentrasi deterjen maka tingkat mortalitas benih ikan karper $(C$. carpio) semakin besar. Setelah melalui uji lanjut, dilanjutkan dengan analisa probit untuk mengetahui nilai $\mathrm{LC}_{50^{-}}-96$ jam, yaitu nilai konsentrasi dimana 50\% dari ikan uji mati dalam waktu pendedahan 96 jam. Berdasarkan perhitungan tersebut, didapatkan nilai $\mathrm{LC}_{50}-96$ jam adalah $21,60 \mathrm{mg} / \mathrm{L}$. Tingkat daya racun berdasarkan nilai $\mathrm{LC}_{50}-96$ jam suatu bahan pencemar pada ikan dibedakan menjadi beberapa kriteria yang dapat dilihat pada Tabel 3.

Tabel 3. Tingkat Daya Racun Berdasarkan Nilai $\mathrm{LC}_{50}-96$ jam

\begin{tabular}{cc}
\hline Nilai $\mathrm{LC}_{50^{-}}-96 \mathrm{jam}$ & Tingkat Daya Racun \\
\hline$<1 \mathrm{mg} / \mathrm{L}$ & Sangat tinggi \\
$1-10 \mathrm{mg} / \mathrm{L}$ & Tinggi \\
$10-100 \mathrm{mg} / \mathrm{L}$ & Sedang \\
$>100 \mathrm{mg} / \mathrm{L}$ & Ringan \\
\hline
\end{tabular}

Sumber: Koesoemadinata (1983)

Berdasarkan kriteria tersebut, dapat kita simpulkan bahwa deterjen dengan kandungan surfaktan berbahan aktif Na-ABS berada pada klasifikasi $10-100 \mathrm{mg} / \mathrm{L}$, yaitu memiliki daya racun sedang. Penelitian yang telah dilakukan sebelumnya (Halang, 2004), nilai $\mathrm{LC}_{50}-96$ jam untuk ikan mas (C. carpio) yang terpapar air limbah deterjen jenis $\mathrm{ABS}$ adalah $36 \mathrm{mg} / \mathrm{L}$. Hal yang membedakan dengan penelitian tersebut adalah besarnya konsentrasi pada uji pendahuluan dan uji lanjut, dimana konsentrasi pada uji pendahuluan berkisar antara $0-2500 \mathrm{mg} / \mathrm{L}$ dan konsentrasi pada uji lanjut berkisar antara $0-50 \mathrm{mg} / \mathrm{L}$. Sedangkan untuk penelitian ini konsentrasi uji pendahuluan dan uji lanjut relatif kecil, yaitu berkisar antara $0,01-100 \mathrm{mg} / \mathrm{L}$ dan 
15,85 - 99,98 mg/L. Seperti yang dipaparkan Mason (1981) dalam Santoso (2010), efek suatu polutan terhadap organisme tergantung pada besarnya konsentrasi polutan tersebut.

3. Uji utama

Uji utama dilakukan pada telur ikan karper ( $C$. carpio) dengan mengamati bagaimana perkembangan daya tetas telurnya pada berbagai konsentrasi sesuai dengan nilai toksisitas $\left(\mathrm{LC}_{50}-96\right.$ jam) yang telah didapat pada uji lanjut. Uji utama menggunakan 5 konsentrasi deterjen, 3 kali pengulangan, dan 1 kontrol, dimana masing-masing akuarium diisi 100 butir telur ikan uji. Konsentrasi bahan uji yang digunakan berdasarkan standar USEPA (2002), yaitu: 6,25\%, 12,5\%, 25\%, 50\%, dan $100 \%$ dari nilai $\mathrm{LC}_{50^{-}} 96$ jam, dimana nilai $\mathrm{LC}_{50^{-}}$ 96 jam adalah 21,60 mg/L. Konsentrasi perlakuan yang digunakan adalah: $\mathrm{K}(0,00 \mathrm{mg} / \mathrm{L}), \mathrm{A}(1,35 \mathrm{mg} / \mathrm{L}), \mathrm{B}$ $(2,70 \mathrm{mg} / \mathrm{L}), C(5,40 \mathrm{mg} / \mathrm{L}), \mathrm{D}(10,80 \mathrm{mg} / \mathrm{L})$, dan E $(21,60 \mathrm{mg} / \mathrm{L})$. Uji utama ini dilakukan untuk mengetahui pengaruh toksisitas deterjen berbahan aktif surfaktan jenis Na-ABS terhadap daya tetas telur ikan karper yang diamati selama 7 hari.

\section{Perhitungan daya tetas telur ikan}

Pengamatan dilakukan dengan estimasi waktu 7 hari, tetapi pada hari ke-4 pengamatan, telur ikan sudah menetas $100 \%$ pada setiap perlakuan dan ulangan, sehingga pada hari berikutnya tidak dilakukan pengamatan lagi. Setelah dilakukan pengamatan terhadap jumlah telur ikan uji yang menetas dan tidak menetas, maka dapat diketahui daya tetas telurnya. Berdasarkan data tersebut kita bisa mengetahui rata-rata harian daya tetas telur ikan per konsentrasi yang dapat dilihat pada Tabel 4.

Tabel 4. Rata-Rata Harian Daya Tetas Telur Ikan Karper (C. carpio) pada Uji Utama

\begin{tabular}{ccccc}
\hline \multirow{2}{*}{$\begin{array}{c}\text { Sonsentrasi Deterjen } \\
(\mathrm{mg} / \mathrm{L})\end{array}$} & I & II & III & IV \\
\cline { 2 - 5 } & 0 & $12 \pm 1,73$ & $92 \pm 1,53$ & 100 \\
2,70 & 0 & $12 \pm 2,00$ & $93 \pm 1,53$ & 100 \\
5,40 & 0 & $5 \pm 2,00$ & $92 \pm 2,00$ & 100 \\
10,80 & 0 & $3 \pm 1,00$ & $87 \pm 1,73$ & 100 \\
21,60 & 0 & $1 \pm 1,00$ & $85 \pm 1,53$ & 100 \\
Kontrol & 0 & $24 \pm 2,00$ & $93 \pm 1,53$ & 100 \\
\hline
\end{tabular}

Grafik rata-rata harian daya tetas telur ikan karper (C. carpio) pada uji utama dapat dilihat pada Gambar 1.

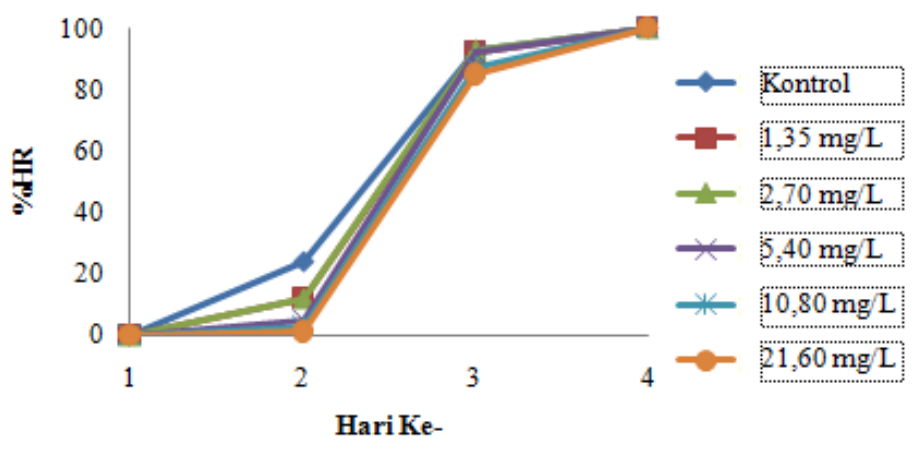

Gambar 1. Grafik Rata-Rata Harian Daya Tetas Telur Ikan Karper (C. Carpio) pada Uji Utama.

Berdasarkan data rata-rata harian daya tetas telur ikan per konsentrasi (Tabel 5 dan Gambar 1), dapat dilihat bahwa pada hari pertama belum ditemukan adanya telur yang menetas pada setiap akuarium. Hari kedua telur sudah mulai menetas. Hari kedua ini disebut sebagai hari kritis karena perbedaan pada tiap konsentrasi deterjennya mulai terlihat nyata, dimulai dari konsentrasi $5,40 \mathrm{mg} / \mathrm{L}$, terlihat perbedaan yang cukup signifikan dibandingkan dengan konsentrasi sebelumnya. Rata-rata Hatching Rate (HR) tertinggi didapat pada konsentrasi 1,35 dan 2,70 mg/L, yaitu $12 \%$, sedangkan untuk rata-rata HR terendah didapat pada konsentrasi $21,60 \mathrm{mg} / \mathrm{L}$, yaitu $1 \%$. Hari ketiga persentase penetasan telur sudah jauh lebih besar dari hari sebelumnya, nilai rata-rata HR tertinggi didapatkan pada konsentrasi $2,70 \mathrm{mg} / \mathrm{L}$, yaitu $93 \%$, sedangkan nilai rata-rata HR terendah didapatkan pada konsentrasi $21,60 \mathrm{mg} / \mathrm{L}$, yaitu $85 \%$. Hari keempat, telur ikan sudah menetas $100 \%$ pada setiap perlakuan dan ulangan, sehingga tidak dilakukan pengamatan terhadap daya tetas telurnya. Nilai HR rata-rata pada akuarium kontrol didapatkan 24\% untuk hari kedua dan $93 \%$ untuk hari ketiga.

Data daya tetas telur ikan tersebut kemudian diuji normalitas dan homogenitasnya menggunakan program SPSS Versi 16. Berdasarkan uji yang telah dilakukan, diketahui bahwa semua nilai signifikansi uji normalitas untuk setiap konsentrasi surfaktan $>\alpha(0,05)$ maka data tersebut terdistribusi normal. Demikian juga untuk uji homogenitas pada setiap konsentrasi surfaktan diperoleh nilai signifikansi $>\alpha(0,05)$. Maka bisa dikatakan varian setiap variabel yang diujikan adalah sama. Setelah dipastikan data tersebar normal dan homogen, analisis selanjutnya adalah uji Anova dua arah (two factorial design) dengan menggunakan selang kepercayaan 95\% $(\alpha=0,05)$. Hasil analisa ragam (Anova) daya tetas telur ikan karper (C. carpio) pada uji utama dapat dilihat pada Tabel 5. 
Tabel 5. Hasil Analisa Ragam (Anova) Daya Tetas Telur Ikan Karper (C. carpio) pada Uji Utama dengan Selang Kepercayaan $95 \%$

\begin{tabular}{lrrrrr}
\hline Faktor yang diuji & $\begin{array}{c}\text { Jumlah Kuadrat } \\
(\mathrm{JK})\end{array}$ & $\begin{array}{c}\text { Derajat } \\
\text { Kebebasan }\end{array}$ & $\begin{array}{c}\text { Rata-Rata } \\
\text { Kuadrat }\end{array}$ & \multicolumn{1}{c}{ F $_{\text {rasio }}$} & Signifikansi \\
\hline Model yang diuji & $150.212,319$ & 23 & $6.530,970$ & $4,702 \times 10^{-5}$ &, 005 \\
Intercept & $179.900,014$ & 1 & $179.900,014$ & $1,295 \times 10^{-3}$ &, 000 \\
Konsentrasi & 477,569 & 5 & 95,514 & 68,770 &, 011 \\
Waktu & $148.968,042$ & 3 & $49.656,014$ & $3,57510^{-4}$ &, 682 \\
kons * waktu & 766,708 & 15 & 51,114 & 36,802 &, 046 \\
Galat & 66,667 & 48 & & & \\
Total & $330.179,000$ & 72 & & & \\
Total yang diuji & $150.278,986$ & 71 & & & \\
\hline
\end{tabular}

Tabel 5 di atas menunjukkan nilai signifikansi untuk variabel konsentrasi adalah 0,011 (Kolom 6, baris 3). Nilai signifikansi $<0,05$ maka $\mathrm{H}_{0}$ ditolak, konsentrasi deterjen mempengaruhi daya tetas telur ikan. Nilai signifikansi untuk variabel waktu adalah 0,682 (Kolom 6, baris 4). Nilai signifikansi > 0,05 maka $\mathrm{H}_{0}$ diterima, waktu pemaparan deterjen tidak mempengaruhi daya tetas telur ikan. Nilai signifikansi untuk variabel konsentrasi dan waktu adalah 0,046 (Kolom 6, baris 5). Nilai signifikansi < 0,05 maka $\mathrm{H}_{0}$ ditolak, daya tetas telur ikan dipengaruhi oleh waktu pemaparan deterjen dengan besar konsentrasi berbeda.

Setelah dilakukan analisis Anova, maka dilanjutkan dengan uji Homogeneous subsets (uji Duncan) untuk melihat perbedaan pada setiap perlakuan. Hasil uji Duncan daya tetas telur ikan karper (C. carpio) dapat dilihat pada Tabel 6.

Tabel 6. Hasil Uji Duncan Daya Tetas Telur Ikan Karper (C. carpio)

\begin{tabular}{cccccc}
\hline $\begin{array}{c}\text { Konsentrasi deterjen } \\
(\mathrm{mg} / \mathrm{L})\end{array}$ & $\mathrm{N}$ & \multicolumn{5}{c}{ Subset } \\
\cline { 3 - 5 } 21,60 & 12 & 46,5833 & 2 & 3 \\
10,80 & 12 & 47,5000 & & \\
5,40 & 12 & & 49,2500 & & \\
1,35 & 12 & & & 51,0833 & \\
2,70 & 12 & & 51,1667 & \\
Kontrol & 12 & & & & 54,3333 \\
Sig. & &, 063 & 1,000 &, 863 & 1,000 \\
\hline
\end{tabular}

Tabel 6 di atas menunjukkan subset 1 terdapat konsentrasi 21,60 mg/L dan 10,80 mg/L, hal ini berarti bahwa kedua konsentrasi tersebut tidak berbeda secara nyata. Subset 2 terdapat konsentrasi 5,40 mg/L dengan nilai mean 49,2500; hal ini berarti bahwa perlakuan dengan konsentrasi $5,40 \mathrm{mg} / \mathrm{L}$ berbeda nyata dengan konsentrasi lainnya. Subset 3 terdapat konsentrasi 1,35 mg/L dan 2,70 mg/L, hal ini berarti bahwa perlakuan dengan konsentrasi $1,35 \mathrm{mg} / \mathrm{L}$ dan $2,70 \mathrm{mg} / \mathrm{L}$ tidak berbeda nyata. Subset 4 hanya terdapat konsentrasi $0 \mathrm{mg} / \mathrm{L}$ (kontrol) dengan nilai mean tertinggi yaitu 54,3333; hal ini berarti bahwa perlakuan dengan konsentrasi $0 \mathrm{mg} / \mathrm{L}$ (kontrol) berbeda nyata dengan konsentrasi-konsentrasi lainnya.

5. Kualitas air

Hasil pengamatan kualitas air pada proses penetasan telur ikan karper (C. carpio) selama 7 hari dapat dilihat pada Tabel 7.

Tabel 7. Hasil Pengamatan Kualitas Air pada Proses Penetasan Telur Ikan Karper (C. Carpio) selama 7 Hari

\begin{tabular}{cccc}
\hline $\begin{array}{c}\text { Konsentrasi Deterjen } \\
(\mathrm{mg} / \mathrm{L})\end{array}$ & \multicolumn{3}{c}{ Kisaran Variabel Kualitas Air } \\
\cline { 2 - 4 }$\left({ }^{\circ} \mathrm{C}\right)$ & Oksigen Terlarut $(\mathrm{mg} / \mathrm{L})$ & $\mathrm{pH}$ \\
\hline 1,35 & $25,30-28,30$ & $2,40-3,43$ & 7 \\
5,70 & $24,77-27,63$ & $2,40-3,30$ & 7 \\
1,40 & $24,37-27,00$ & $2,40-3,30$ & 7 \\
21,60 & $24,73-27,40$ & $2,40-3,27$ & 7 \\
Kontrol & $24,77-27,33$ & $2,37-3,17$ & 7 \\
\hline \multirow{2}{*}{ Nilai optimum } & $24,70-27,20$ & $3,00-4,00$ & $6,7-8,2$ \\
& $27-30^{\circ} \mathrm{C}$ & Min. 3 mg/L & Boyd (1990) \\
\hline
\end{tabular}


Tabel 7 di atas menunjukkan kisaran beberapa variabel kualitas air pada setiap konsentrasi deterjen. Variabel suhu berada pada kisaran $24,37^{\circ} \mathrm{C}-28,30^{\circ} \mathrm{C}$, nilai tersebut masih berada pada kisaran nilai optimum untuk pemijahan ikan karper yaitu $27-30^{\circ} \mathrm{C}$ (Arie, 2008). Berdasarkan tabel tersebut, diketahui bahwa adanya paparan deterjen dengan berbagai konsentrasi tidak berpengaruh terhadap suhu air, karena fluktuasi nilai suhu air terlihat sama pada semua konsentrasi. Variabel oksigen terlarut berada pada kisaran 2,37 - 4,00 mg/L. Kandungan oksigen terlarut cenderung menurun seiring dengan adanya peningkatan konsentrasi deterjen. Kandungan oksigen terendah terjadi pada konsentrasi deterjen $21,60 \mathrm{mg} / \mathrm{L}$ yaitu pada kisaran 2,37 - 3,17 mg/L. Sedangkan kandungan oksigen tertinggi ada pada kontrol, pada kisaran 3,00-4,00 mg/L. Menurut Hardjamulia (1981), selama penetasan telur, oksigen dalam air tidak boleh kurang dari $3 \mathrm{mg} / \mathrm{L}$. Perairan yang terkena polutan seperti deterjen, suplai oksigen dari udara sangat lambat sehingga oksigen di dalam air sedikit. Nilai $\mathrm{pH}$ yang didapatkan pada setiap perlakuan adalah 7 , yang berarti $\mathrm{pH}$ air dalam keadaan netral. Besarnya nilai $\mathrm{pH}$ setiap perlakuan selama penelitian adalah sama, hal tersebut menandakan bahwa larutan surfaktan tidak berpengaruh terhadap pH air. Menurut Boyd (1990), pH yang optimal untuk penetasan telur ikan berkisar antara 6,7 - 8,2.

\section{Kesimpulan}

Berdasarkan penelitian yang telah dilakukan, maka kesimpulan yang didapat adalah sebagai berikut:

1. Nilai konsentrasi sublethal (LC50-96 jam) yang diperoleh dari deterjen jenis surfaktan berbahan aktif NaABS terhadap ikan karper (Cyprinus carpio) adalah 21,60 mg/L; dan

2. Kandungan deterjen jenis surfaktan berbahan aktif Na-ABS berpengaruh terhadap penetasan telur ikan karper (C. carpio). Semakin besar konsentrasi deterjen, maka semakin kecil persentase daya tetas telur (hatching rate) pada setiap harinya. Pengaruh deterjen mulai terlihat nyata pada konsentrasi $5,40 \mathrm{mg} / \mathrm{L}$, dengan waktu kritis yaitu pada hari kedua.

\section{Daftar Pustaka}

APHA (American Public Health Association). 1995. Standar Method for the Examination of Water and Waste Water. Nineteenth Edition. American Public Health Association, American Water Works Association and Water Polution Control Federation, Washington DC.

Arie, U. 2008. Budidaya Ikan Mas-Penetasan Telur Ikan Mas. http://solusiikanmas.blogspot.com. Diakses tanggal 15 Mei 2013.

Bangsa, P. H. 2013. Pembelajaran 6: Penetasan Telur Ikan. http://id.scribd.com/doc/32697323/PENETASANTELUR-IKAN. Diakses tanggal 15 Mei 2013.

Billard, R., O. Linhart, S. Kudo, V. Slecthta, and E. V. Mikodina. 1995. Morphology, Composition and Fertilization of Carp Eggs: a Review. Aquaculture, 129:75 - 93

Boyd, C. E. 1990. Water Quality in Ponds for Aquaculture. Birmingham Publishing Co, Alabama, 453 p.

Effendi, H. 2000. Telaahan kualitas air bagi pengelolaan sumberdaya dan lingkungan perairan. Fakultas Perikanan, IPB, Bogor, $258 \mathrm{hlm}$.

Effendie, M. F. 1979. Metode Biologi Perikanan. Cetakan I, Yayasan Dewi Sri, Jakarta.

Halang, B. 2004. Toksisitas Air Limbah Deterjen terhadap Ikan Mas (Cyprinus carpio). Program Studi Biologi. FKIP Universitas Lambung Mangkurat. Bioscientiae, 1(1): 46 - 47.

Hardjamulia, A. 1981. Daya Kelangsungan Hidup ikan Mas (Cyprinus carpio Linn) dalam Berbagai Turbiditas. [Tesis]. Program Pascasarjana, Institut Pertanian Bogor, $81 \mathrm{hlm}$.

Husni, H. 2011. Uji Toksisitas Akut Limbah Cair Industri Tahu terhadap Ikan Mas (Cyprinus carpio Lin) (Studi Kasus: Limbah Cair Industri Tahu "SUPER”, Padang). Jurusan Teknik Lingkungan. Universitas Andalas. Padang.

Koesoemadinata. 1983. Pedoman Umum Pengujian Laboratorium Toksisitas Lethal Pestisida pada Ikan untuk Keperluan Pendaftaran. Komisi Pestisida Departemen Pertanian, Jakarta, 24 hlm.

Rubiyatadji, R. 1993. Penurunan Kadar Deterjen (Alkyl Benzene Sulphonate) dalam Air dengan Proses Adsorpsi Karbon Aktif. Tugas Akhir. Program Studi Teknik Lingkungan, ITS, Surabaya.

Santoso, L. 2010. Kajian Toksisitas dan Bioakumulasi Surfaktan Deterjen Linear Alkylbenzene Sulfonate (LAS) pada Juvenil Udang Galah (Macrobrachium rosenbergii). [Tesis]. Program Pascasarjana, Institut Pertanian Bogor, Bogor, 77 hlm.

USEPA (United States Environmental Protection Agency). 2002. Method for Measuring the Acute Toxicity of Effluents and Receiving Waters to Freshwater and Marine Organism. Fifth Edition. EPA-821-R-02-012. Office of Water (43035). Washington, DC. 